\title{
The Effect of Dates (Phoenix dactylifera) on Breast Milk Production in Post Partum Mother Day 3-9
}

\author{
Rahma Kusuma Dewi, Dewi Nur Afifi, Alfika Awatiszahro, Wartinah, Dina Yulianti \\ Midwifery Proffesion Program, Faculty of Health Science, Kadiri University, Indonesia \\ Email: rahmakusumadewi@unik-kediri.ac.id
}

Article history:

Received: March 8, 2021

Revised: April 24, 2021

Accepted: May 12, 2021

Keywords:

Dates,

Breast Milk,

Post Partum.

\begin{abstract}
Mother's Milk (ASI) is the best food for babies that is produced directly from the mother's breast to her newborn baby, because its composition is appropriate for every baby's growth and development, breast milk also contains protective substances that can prevent babies from various infectious diseases. Dates contain iron, protein, fiber, glucose, vitamins, biotin, niacin, folic acid, and minerals such as calcium, sodium, and potassium which can increase breast milk production. The purpose of this study was to determine the effect of dates on breast milk production in postpartum mothers on days 3-9 at PMB Binti Qoni'ah Nganjuk 2021. The design of this study was pre-experimental using a one-group pre-posttest design. In this study obtained a population of 15 people, with a sample of 15 people using total sampling technique. The data was collected using an observation sheet and the hypothesis test used was the Wilcoxon Signed Rank Test with a significance value $=0.05$. The statistical test result from the Wilcoxon Sign Rank obtained p value $=0,01$ with an error level $(=0.05)$, it can be said that $\mathrm{p}<$ than it can be concluded that Ho is rejected and $\mathrm{H} 1$ is accepted. There is an effect of dates on breast milk production in postpartum mothers on days 3 - 9 at PMB Binti Qoni'ah Nganjuk 2021. Based on the results of the study, it is hoped that the research area can be used as input for using dates to increase breast milk production in the development of traditional medicine
\end{abstract}

\section{Introduction}

The future of society depends on the health of its children. In the starting phase, breast milk is approximately the ideal food that has beneficial [1]. Low breastfeeding is a threat to the growth and development of infants, if exclusive breastfeeding is not given, the baby will be vulnerable to malnutrition and have a major effect on the growth and development and endurance of children[2]. Breast milk is a unique solution to provide ideal nutrition for babies. Evidence has shown that breastfeeding for the first six months is the most desirable method [3] Breastfeeding is widely recognized to provide health benefits for both mother and $\mathrm{k}$ [4]. Breastfeeding is the best way to feed her young, and it improves the health and development of mothers and their newborns[5]. Breastfeeding provides health benefits for women and children [6]. Breastfeeding babies immediately after birth can help prevent infant mortality [7].

Breastfeeding is considered the most important source of nutrition in the first year of life for term infants and premature infants due to its well-known positive effects on short and long term outcomes[8]. Breastfeeding mothers experience both ups and downs during the breastfeeding process. Inadequate knowledge of breastfeeding, intergenerational disagreements about dietary supplements that can inhibit lactation, and lack of professional support lead to problems in breastfeeding [9]. Many women express concern about their ability to produce sufficient breast milk, and insufficient breast milk is often cited as a reason for stopping breastfeeding [10]. Many postpartum mothers try to increase their milk production by using natural galactagogues and choose not to use high-risk synthetic galactagogues. Consumption of adequate nutrition by breastfeeding mothers can increase milk production[11].

Consumption of sufficient nutrients by breastfeeding mothers on a relatively regular basis increases the production of breast milk with good affection [12]. ates are one of the oldest plants cultivated by humans and have been widely consumed for more than 6000 years. It contains 
nutritional value, fructose and glucose. In addition, it also consists of minerals (selenium, copper, potassium, and magnesium), and $\mathrm{B}$-complex vitamins and vitamin $\mathrm{C}$, and oxytocin, which can stimulate to facilitate uterine contractions [13].

All varieties of Dates serve as good sources of natural antioxidants and are potentially considered as functional foods or functional food ingredients[14]. Dates contain steroid alcohol or sterol compounds such as cholesterol, campesterol, stigmasterol, beta-sitosterol, and isofukosterol. Steroid alcohols, led by cholesterol, are precursors to the production of glucocorticoid steroids and estrogens. Progesterone and estrogen play a role in lactation, evolution, and proliferation of the breast ducts and alveoli, and low doses stimulate prolactin secretion [5]. Milk production is influenced by the hormone oxytocin. Oxytocin can be obtained in various ways, either through oral therapy, or food (dates, fenugreek), intra-nasal, intra-muscular, or by massage that stimulates the release of the hormon oxytocin [15].

\section{Method}

\section{A. Design and Samples}

The study design is a pre experiment that is one group pretest-posttest design. The independent variable in this study was dates. The dependent variable in this study was the production of breast milk in post partum mothers on days 3-9. The research instruments were in the form of observation sheets and SOPs. The sample in this study were some of the active phase I inpartu mothers at PMB Binti Qoni'ah Nganjuk.

\section{B. Data Collections}

The type of data collected is the type of primary data obtained from observations after giving 100 grams of wet dates without seeds per day, given for 7 days. The palm fruit is consumed directly without any modification, taken two times a day, once ate 50 grams of time after breakfast and after dinner, se has intervened for 7 days, observations back to see an increase in milk production on day 10.

\section{Data Analysis}

Statistical tests for both variables used the Wilcoxon test. All tests are done by using SPSS for Windows 24

\section{Results and Discussion}

The results of this study showed that the benefits of eating fruit palm on days 3-9 postpartum maternal effect on the smooth running of the milk.

Table 1. Effect of date palm (Phoenix Dactylifera) on breast milk production in post partum mothers on days 3-9

\begin{tabular}{|c|c|c|c|c|}
\hline \multirow[b]{2}{*}{ Category } & \multicolumn{2}{|c|}{$\begin{array}{l}\text { Before consuming dates (Phoenix } \\
\text { Dactylifera) }\end{array}$} & \multicolumn{2}{|c|}{$\begin{array}{l}\text { After consuming dates (Phoenix } \\
\text { Dactylifera) }\end{array}$} \\
\hline & Frequency & $\%$ & Frequency & $\%$ \\
\hline Fluent & 0 & 0 & 12 & 80 \\
\hline Not Smooth & 15 & 100,0 & 3 & 20 \\
\hline Amount & 15 & 100,0 & 15 & 100,0 \\
\hline$P$ value $=$ & 0,001 & & $\alpha=0,05$ & \\
\hline
\end{tabular}

Based on table 1 above, it can be interpreted that almost all (80\%) of the respondents, namely as many as 12 people experienced smooth milk expenditure after being given dates. Based on the statistical test results from the Wilcoxon Sign Rank with SPSS 20, the P value $=0.001$ is smaller 
than the value $=0.05$ so that $\mathrm{H} 0$ is rejected and $\mathrm{H} 1$ is accepted, meaning that there is an effect of dates ( Phoenix Dactylifera) on breast milk production in postpartum mothers day $3-9$.

Dates provide a wide variety of essential nutrients, and are an excellent source of dietary potassium. The sugar content of ripe dates is about $80 \%$; the remainder consists of protein, fiber, and trace elements including boron, cobalt, copper, fluorine, magnesium, manganese, selenium, and zinc [16]. Besides being able to help uterine contractions, the hormone oxytocin can also contract the blood vessels around the mother's breasts, which will facilitate milk production [17]. Dates contain oxytocin and many chemical elements that are good for nursing mothers [18].

\section{Conclusion}

The results of this study indicate that the benefits of consuming dates have an effect on breast milk production. Dates can be used as an alternative to facilitate the production of breast milk in post partum mothers

\section{Acknowledgment}

The author is thankful to PMB Binti Qoni'ah, Nganjuk Regency, East Java respondents for their valuable information and their awareness to participate in this research.

\section{References}

[1] G. H. R. Sharifirad, H. Shahnazi, E. Sedighi, and B. Mahaki, "The Effect of Supporter Presence in Education Sessions of Breastfeeding on Knowledge, Attitude and Behavior of Nulliparous Women," J. Heal. Hyg., vol. 9, no. 1 \#f00552, pp. 45-61, 2018.

[2] R. Angriani, E. Sudaryati, and Z. Lubis, "Hubungan Frekuensi Menyusui dengan Kelancaran Produksi ASI Ibu Post Partum di Wilayah Kerja Puskesmas Peusangan Selatan Kabupaten Bireuen Provinsi Aceh Tahun 2017," J. Muara Sains, Teknol. Kedokteran, dan Ilmu Kesehat., vol. 2, no. 1, pp. 299-304, 2018.

[3] M. Adeli, S. Alirezaei, M. Kabiriyan, and F. Rafiei, "A comparison of the effect of short abdominal skin-to-skin contact and kangaroo skin contact on initiation of successful breastfeeding," J. Babol Univ. Med. Sci., vol. 20, no. 2, pp. 70-76, 2018, doi: 10.18869/acadpub.jbums.20.2.70.

[4] C. G. Victora et al., "Breastfeeding in the 21st century: epidemiology, mechanisms, and lifelong effect.," Lancet (London, England), vol. 387, no. 10017, pp. 475-490, Jan. 2016, doi: 10.1016/S0140-6736(15)01024-7.

[5] F. Saeed Ebrahimi, M. Hemmati, and M. Malekaneh, "Effects of the date palm fruit (Phoenix dactylifera L.) on prolactin, IGF-1, and stress factors in lactating female rats and its impact on their litters' development," Med. J. Nutrition Metab., vol. 10, no. 3, pp. 251258, 2018, doi: 10.3233/MNM-17164.

[6] K. Cato, S. M. Sylvén, H. W. Henriksson, and C. Rubertsson, "Breastfeeding as a balancing act - pregnant Swedish women 's voices on breastfeeding," vol. 0, pp. 1-9, 2020.

[7] S. B. Pertami, B. Budiono, and I. Rahmawati, "Optimizing the Endorphin and Oxytocin Massage to Increase Breast Milk Production among Postpartum Mother in Indonesia," NurseLine J., vol. 5, no. 1, p. 214, 2020, doi: 10.19184/nlj.v5i1.16825.

[8] Z. Ali, M. Bukari, A. Mwinisonaam, A. L. Abdul-Rahaman, and A. R. Abizari, "Special foods and local herbs used to enhance breastmilk production in Ghana: rate of use and beliefs of efficacy," Int. Breastfeed. J., vol. 15, no. 1, pp. 1-9, 2020, doi: 10.1186/s13006020-00339-z.

[9] X. Xiao, A. Y. Loke, S. ning Zhu, L. Gong, H. mei Shi, and F. wan Ngai, “"The sweet and 
the bitter': Mothers' experiences of breastfeeding in the early postpartum period: A qualitative exploratory study in China," Int. Breastfeed. J., vol. 15, no. 1, pp. 1-11, 2020, doi: 10.1186/s13006-020-00256-1.

[10] S. C. Foong, M. L. Tan, W. C. Foong, L. A. Marasco, J. J. Ho, and J. H. Ong, "Oral galactagogues (natural therapies or drugs) for increasing breast milk production in mothers of non-hospitalised term infants," Cochrane Database Syst. Rev., vol. 2020, no. 5, 2020, doi: 10.1002/14651858.CD011505.pub2.

[11] V. Ghasemi, M. Kheirkhah, M. Vahedi, S. Darabpour Dezdarani, and M. Abed, "Comparison effect of herbals tea containing fenugreek seed and fennel seed on the signs of breast milk sufficiency in iranian girl infants with 0-4 months of age," J. Med. Plants, vol. 17, no. 68, pp. 166-174, 2018.

[12] R. Tafrishi, S. Shekari, M. Ajam, E. Barati, and S. Masoud, "The Effect of Dates and Fennel on Breastfeeding Adequacy of Mothers : A Review," vol. 8, no. 8, pp. 11891-11899, 2020, doi: 10.22038/ijp.2020.46760.3795.

[13] A. El Sakka, M. Salama, and K. Salama, "The Effect of Fenugreek Herbal Tea and Palm Dates on Breast Milk Production and Infant Weight.," J. Pediatr. Sci., vol. 6, no. 0, 2014, doi: $10.17334 / j p s .30658$.

[14] S. H. S. Alghamdy, A. M. Hassan, and S. A. Mohammad, "Protective Effect of Date Fruit Extract Against Ochratoxin a . Genotoxicity and Hepatotoxicity in Mice .," Al-Azhar Assiut Med. J., vol. 11, pp. 276-310, 2013.

[15] D. Yulinda and I. Azizah, "Pengaruh Sari Kurma Terhadap Prolaktin Dan Pengeluaran Asi Pada Ibu Postpartum Di Bpm Pipin Heriyanti Yogyakarta Tahun 2017," Media Ilmu Kesehat., vol. 6, no. 3, pp. 195-198, 2019, doi: 10.30989/mik.v6i3.196.

[16] P. R. Pehrsson, D. B. Haytowitz, J. M. Holden, C. R. Perry, and D. G. Beckler, "USDA's national food and nutrient analysis program: Food sampling," J. Food Compos. Anal., vol. 13, no. 4, pp. 379-389, 2000, doi: 10.1006/jfca.1999.0867.

[17] O. Al-Kuran, L. Al-Mehaisen, H. Bawadi, S. Beitawi, and Z. Amarin, "The effect of late pregnancy consumption of date fruit on labour and delivery," J. Obstet. Gynaecol. (Lahore)., vol. 31, no. 1, pp. 29-31, 2011, doi: 10.3109/01443615.2010.522267.

[18] M. N. W. Siti Roudhatul Jannah, "Comparing Effectiveness Of Palm Dates And Oxytocin Massage In Stimulating Breastmilk Production Of Post Partum Mother," Int. Conf. Appl. Sci. Heal., no. 33, pp. 63-69, 2014. 